\title{
Underwriter reputation and IPOs performance
}

\author{
Dildar Khan Jadoon* , and Hazarat Ali**
}

*Postgraduate student at COMSAT Abbottabad

** Postgraduate student at COMSAT Abbottabad

*Corresponding author:

kjadoon135@gmail.com 


\begin{abstract}
:
In this paper, it is defined that how the IPOs are affected by the underwriter reputation. What will happen to IPOs who are backed by reputed underwriter and who is not? And evaluate the IPOs short-run and long-run performance. Also try to explain the relationship between IPOs and underwriter. Also tried to compare some of the international return and Pakistani returns. Also determine the relation of the investor to the underwriter. There is a set of investors who have their relationship with the underwriters how they will affect on the IPOs in the market.
\end{abstract}

Keywords: Underwriter, IPO's, Performance, underwriter reputation, IPO's Performance, 


\section{TABEL OF CONTENTS}

\section{Contents}

\section{Contents}

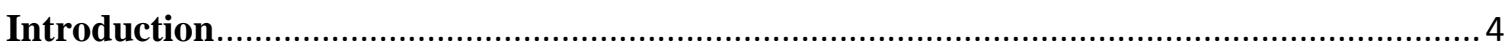

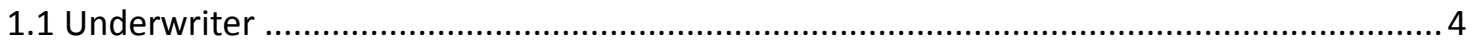

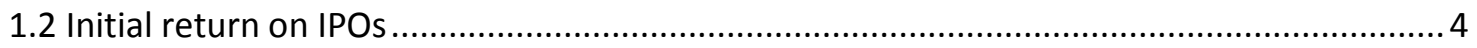

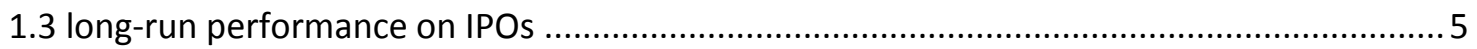

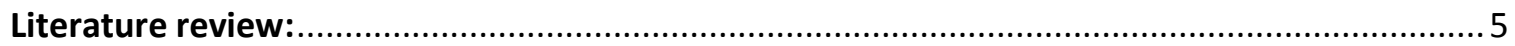

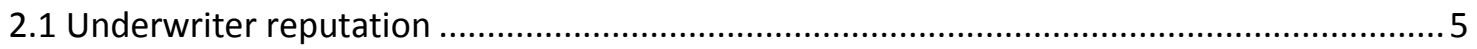

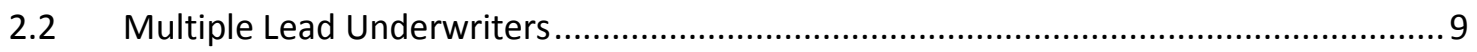

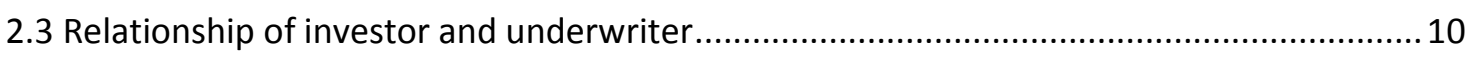

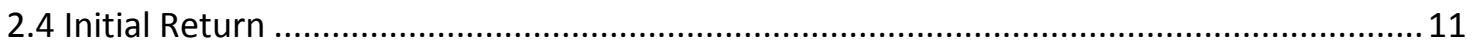

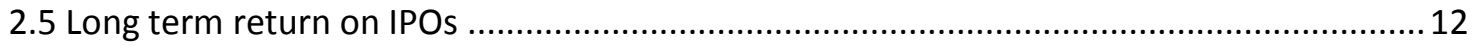

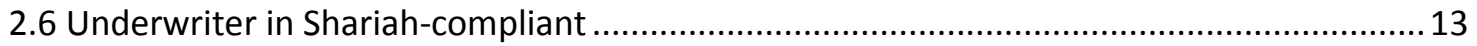

2.7 Underwriter reputation and IPOs performance in Pakistan stock exchange (KSE) ............14

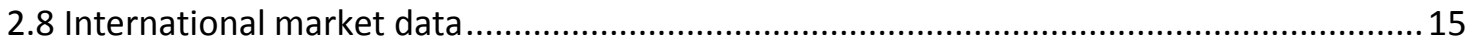

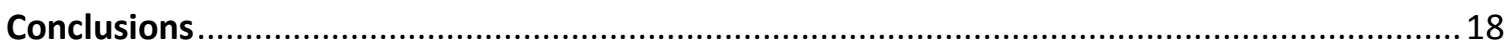




\section{Introduction}

\subsection{Underwriter}

All over the globe, the firms want to maximize their capital. For this purpose, they need to issue their shares to the general public. Firms need some help in this regard so they need an underwriter. An underwriter is the person who helps in introducing the firm's securities to the market. These securities are called IPOs Initial Public offerings. When a firm wants to issue IPOs, they hire underwriter. Underwriter makes a promise to sell the companies share to the public. Underwriter assures to sell all shares because the underwriter agreed to compensate against the share though all shares may not be sold. The underwriter tries to sell all of the shares but when some shares remain unsold, they are returned to the firm.

The role of the underwriter is very important in firms IPOs performance. The firm use underwriter to achieve monitory performance. Underwriter helps to increase corporate performance. And also helps in less cost in getting capital. The firm use underwriter for various benefits such as firm uses them to increase capital. And if the firm wants to increase its investor base then it needs a good underwriter. Underwriter also helps in the marketing function of IPOs of firm. Underwriter also helps in increasing the investor base of the firm. Underwriters have very skilful knowledge about the financial market. Underwriter's primary services include the guidance of issuing IPOs on accurate time, issuing shares, the long-run performance of IPOs.

One of the most significant tasks of an underwriter is to set a final price. When the price is set, the firm will be able to know how much capital they can get and on how much issuing of shares. And it also makes the task of underwriter easy to sell the shares easily.

\subsection{Initial return on IPOs}

As we very well know that capital is life-line of any business. Capital can be arranged in different ways. One of the important methods is offering of equity to the public and is known as Initial Public Offering IPOs. When some company issue IPOs they are mostly underpriced but after trading in the secondary market their average goes high from IPOs 
price. A positive return on an equity that an owner of security received on buying of new security IPOs when sold at a closed price.

An investor may estimate the return of IPOs from the information, if the market is informatics efficient. So, if an investor is interested in buying or if he sees some potential in the security, he will pay a high price for it. When investors see company previous performance then he will buy IPOs.

\section{3 long-run performance on IPOs}

Here we discuss the IPOs long-run performance. When the IPOs are offered some time, they are not bought well but their performance in long terms is quite well. The performance of IPOs in the long-run is quite interesting for the investor.

The long-run performance of IPOs is affected by some factors, they may be, the structure of the firm, capital and underwriter's reputation. Except this the result of the previous long-run performance of IPOs is like the more profitable firm has not shown good and the companies which have a big size can gain more investor

In this study primary focus is on underwriter's reputation in increasing capital and the role of the underwriter in issuing IPOs. Services of underwriters which they offered to the firm. How much is the initial return on IPOs and also the performance of IPOs in the long run?

\section{Literature review:}

Previous studies on Underwriter reputation shows that is the reputation related to the underwriter is good there will be sound IPOs can have issued to the public.

\subsection{Underwriter reputation}

Lee (2011) concluded that when a firm hired reputable underwriter it would have a high marketability when it is offered for the general public. He also highlighted the effectiveness of underwriter in issuing of IPOs on accurate time. The underwriter recommends the firm to adjust price, issuing time, finally issuing.

The important thing is presenting IPOs at a suitable time by the underwriter, if underwriter can forecast a suitable timing of issuance of IPOs, he will be able to capture more market share. This he can do with previous experience and knowledge that he has about the market. 
As we know, engineers, accountants, barristers etc., they are only answerable for certain components. The responsibility of underwriters is to focus on the market and be aware of markets ups and downs, have a good knowledge about what is going on in a market and also the decision of offering time, firm creditability. Underwriter must know the variation in the market.

This study is based on empirical evidence that underwriters are more capable of presenting IPOs on time. Underwriters in making businesses free beneath additional satisfactory industry circumstances, when effective control presentation is calculated by the alteration in market-adjusted returns on the size and industry corresponding index over the coming up period.

Huang (2011) asked that in the end of 20th and starting periods of 21 st century, the underwriter reputation didn't have any effect on the IPOs performance but now it has a huge impact on the performance of the IPOs. But in the same array, there is somehow the impact of underwriter is on the IPOs but it is too minor that it is not significant to calculate. As the increase in the value of underwriter now it converted to hire a good underwriter who has a vital role for IPOs. Furthermore, from the data calculated between 1999-2004 tells us that there is no relation between the underwriter and the firm IPOs.

But from 2005-2012 the ratio related to underwriter gradually increased. The ratios of fist array are not very important or have any positive relationships because it was $10 \%$ only. But after that, as the underwriter increased their value it became important and now it has a positive relation of the reputation of an underwriter and firm value of IPOs.

Wang (2003) documented the connection of reputed sponsor of IPOs value of organization and presentation of IPOs in the market. The underpricing of the IPOs is directly related to the reputation of the underwriter. The firms who have reputed underwriters will able to perform very well in the market. When the IPOs are presented then it will be very much affected by the underwriter reputation. Good and sound reputed underwriter will always back up his presented share and due to his good value in the investor`s mind, the investor gets interested to buy his share.

In the long run, the performance of the IPOs is quite impressive and it gives an optimistic result. There is much positive result shown in the long run of the IPOs 
performance which is backed by a reputed underwriter. The consequences provide the argument that IPO revenues are correlated with underwriter status and improved investment bankers have a better capability to forecast upcoming effectiveness of issuing companies

Akkus \& Cookson (2014) documented that the permutation of the underwriter will have a great effect on the value in underpricing of IPOs shared to market. He used two dimensions to define this concept "certification and strategic underpricing". Companies need a reputed underwriter to control all the information of the market and to give room to share a security at a time where it can be taking good response. Underwriter provides security to the company of selling the shares. On the other hand, a good underwriter in strategic technique has a habit of underpricing to build a strong association between underwriter and investor. The underpricing in the first method was less than $2.0 \%$. In this method, the periodical sequence of IPOs possession was determined over the time. While in the second method is improved by $2.5 \%$ and here it is more important respectively. This result explains the underwriter reputation.

The firms need to reduce the information asymmetries for attracting more investors to invest in their stocks. For this purpose, firms need to hire a good underwriter who has a good reputation in the market and also to set a good price of IPOs on which an investor should able to invest in the stock of the company. The underwriter underprices the IPOs to attract more investor and then with his sound relation he will able to sell more shares to the investor. The underwriter reputation and other features are directly proportional to the performance of IPOs in the market.

The selection of the method of sharing of IPOs is also a sign of the reputed underwriter. But in the either way strategic or certification the primary role is of underpricing of the share.

The IPOs performance is very much related to the reputation of the underwriter. The underwriter may help in providing the services of IPOs price modification and the relation of the IPOs in the secondary market performance, initial return on the IPOs. The best underwriter is related with the price adjustment, better IPOs and aftermarket evaluation, initial return on the IPOs. Investor better-recognized equity, the return on the IPOs in the long run. Bajo, Chemmanyr, Simonyan and Tehranian (2014). 
The performances of the IPOs in short as well as in the long run are directly affected by the policies of the underwriter. If the underwriter can develop marketoriented policies, the share they are going to sale has a good market value and when the IPOs underwriter is not able to interpret the right decision then there will be some variation in the result of the performance of the IPOs in the market. In over-all, principal IPO underwriters extra are set within investment banking networks are reliably and the Underwriter professionally distributes their satisfactory remote information of the company in the public and to the investors.

Karolyi, Lehn and Mulherin (1999) examine that the lead underwriter plays a rule of "book manager" in performance of IPOs. There is a negative effect of the underpricing of the IPOs in the long-run performance of the IPOs. The long-run performance of the share is very much linked with the underpricing of the IPOs. The factor of risk also needs to be in concentration because the investor banks are taking the risk of the company on its own.

The lead underwriter may affect the return of IPOs, extended track performance, attentiveness returns on the industry. The relation of the reputable bank and long-term return is optimistic. The result of the initial return as to the long-term performance is inversely proportioned to each other. The charges of the reputed underwriter are quite high as of the other.

"Bear Stearns, Lehman Brothers, Merrill Lynch, and Wachovia" these companies price decreased on the opening day of IPOs the decrease was only $2 \%$ that suffer the $\$ 3$ billion loss. This loss shows that the underwriter has a great impact on the observing and controlling of IPOs Kovner (2010)

The lead underwriter is very much significant because besides the price-fixing, securities posted in time, controlling the information asymmetry and to gather investor, they stay in touch with their previous IPOs. When a firm has more than one underwriter, they divert their risk to more than one parties and this is a win-win situation for both the company and for the underwriters. The underwriter is playing the role of a creditor of the company, make a market for company IPOs and if in the IPOs company able to do well with the help of the lead underwriter then this is a green ticket for the firm to do well in the long run and to get a goodwill among the investors so in a feature the firm will able to 
get the maximum generation of income for further issuing of IPOs but the other factor says the firm reputation, profits, dividend may also have an impact on this.

The firms while selecting the underwriters need to evaluate the underwriter reputation among the investors, the previous track record of issuing of IPOs and financial status of the underwriter.

Loo, Lee and Yi (1999) reviewed that the lead underwriter is responsible for the success of the company's IPOs. If the firm hires a well-reputed underwriter, then the IPOs of the firm is less unstable as an associate with those firm who are not interested in hiring a recognized underwriter with a lead experience and investor reputation.

The productivity of the firm IPOs is very much linked with the reputation of lead underwriter. One another dimension is this older underwriter or investor firm has very much value in the investor due to their experience and their sustainability in the market. The IPOs issued by the lead underwriter has a high efficacy due to the trust of the investor on the underwriter. The risk is also remaining very less with the IPOs backed by the lead underwriter.

Song, Choi and Lee (2012) enlist the underwriter character behind the observing the firm IPOs when they are going to the public their share. To reduce the asymmetric information, the underwriter, play an important role in it. The correlation among the underwriter and the IPOs underpricing is very positive.

\subsection{Multiple Lead Underwriters}

Vithanage, Chung and Neupane (2016) say that the influence of the prime underwriter has a positive relationship on the performance of the IPOs. On explanation for the information that is superior making and distributions have to decrease the investor dissimilar beliefs in the performance of the IPOs. The IPOs which are underwritten by the multiple underwriters in performance have more importance than those who are sponsored by the one underwriter. The performance of the IPOs under multiple lead underwriters has usually high capacity as substitutions of dissimilar belief, bid and ask range, predictor spreading and exchange, return instability.

The IPOs backed by the several underwriters are displayed as the more suggestively less deviating for the investor as compare to the IPOs backed by the single investment bank. The IPOs of the many underwriters have very low underpricing in the 
market and have a good performance in the long run as compare to single. Miller (1977) says that deviation of view reasons short-term above appraisal of IPOs and long-run deficit.

Song (2003) states that when a firm hires a group of underwriters the firm can get good services from them so in this way the firm also receive a good price. The underwriter performed a necessary role in giving some valuable investments in financial markets. Also, they have a very positive effect on the economy. They also get the trust from the investor. The underwriter is in a group or separated have a virtuous effect on companies IPOs and investor interest.

\subsection{Relationship of investor and underwriter}

Neupane \& Thapa (2013) inspect the relationship of investor and underwriter in the light of underwriter reputation. There is a positive relationship between investor and reputable underwriter. The IPOs presented by the underwriter of good status attract a large number of investors while on the other hand when there is an underwriter with a less reputation, he will have a smaller number of investors. Investors prefer to invest in the IPOs backed by the reputed underwriter.

The position of a reputed underwriter is quite good in the issuing of IPOs. It is also noticed that the relationship of an underwriter with the investor plays a key role in keeping IPOs good. The efficacious IPOs offering by a good underwriter has a positive relationship with the investor. The underwriters who do not have a good reputation in the market have little or no influence in the market so that he can't do any good while offering IPOs in the market.

An underwriter who has a good reputation will have a full grip on the market. He is always predicting what will or will be happened or happening in the current market so the information efficiency is one of the main things that an underwriter should consider.

Neupane \& Thapa (2013)" the underwriter reputation is one of the major factors among the good relation between the underwriter and the investor. There is a different type of investors in the market and most of them have a strong relationship with the good lead reputed underwriter.

There is a huge importance of the relation of the underwriter with the investor. Because of a good relation, the huge official investor invests in early IPOs of the 
underwriter whose reputation in the market is quite high. There is no empirical evidence about how this relationship works but the IPOs of the reputed underwriter is very well dealt in the primary market as compared to the underwriter with less reputation. The underwriters who have a high reputation know the all information revolving in the market. But the underwriters who haven't got a good reputation never pay full attention to all information that is revolving in the market.

\subsection{Initial Return}

Razafindrambinina and Kwan (2013) asked that to gain the initial return on the equity, firm issue their IPOs to market. The return on the IPOs initially disrupted by the performance of the underwriter and the other financial features that are involved in the making firm goodwill.

There are many capital markets in the world which have underpricing problems. And most of the time the performance of the IPOs is underpriced so most of the investors should attract to it. The firms who presented their shares to primary market as an IPOs get a maximum capital when they have a hired a reputed underwriter there is a very positive relationship between the IPOs performance in the primary market and the reputation of the underwriter. The underpricing of the share when IPOs is presented on the very first day is due to recognized to the will to attract the investor to buy a maximum share. The information related to the share price is however controlled by the underwriter which will help the investor to invest.

Whenever the investor has a lack of knowledge about the market then a wellreputed underwriter well is an indication of the IPOs performance in the market. The lead underwriter has maximum information about the market and he will timely present his share so the investor can get information from the lead underwriter. As an investor one should pay a very much consideration to the status of the financier who is issuing the firm IPOs in the collaboration of the firm. Firm who want to go to a public and want to issue IPOs need to pay more consideration on the selection of the lead underwriter. Lead underwriter will help the firm in raising the level of underpricing which helps the firm in long-run performance. 


\subsection{Long term return on IPOs}

Ghosh, Petrova, Feng, \& Pattanapanchai (2012) argued that the return on the IPOs is foreseeable from secluded data available but the data related to the public is not approachable. The important thing is that affect the pricing of IPOs is firm value the profits of the firm which they previously declared. The top management of the firm also plays an important role in the value pricing of IPOs in the market because the investor will be very cleared about to whom he will give his money.

The return from the market on the IPOs is directly related to the performance of the firm in the market. If the firm is doing well it will have a positive effect on the value of the IPOs. The magnitudes of the offering are also important and have a positive effect on the value of IPOs.

Ritter (1991) mention that the firm take good opportunities to do well in the IPOs while having a good performing while they have a high value related to the firm which has a not good value. The IPOs has a represented firm value so the firm is being contingent on the value of the IPOs. The firm which is in a stage of underperformance will not able to get a good timing and will not adjust himself with the timing of the market but later, in the long run, will able to get good profit

Due to the global investment opportunities, the investor becomes more conscious about investing in the market because to diversifying the risk pattern an investor tries to invest in a portfolio which has a low correlation with other. If the firm value being not at that position so investor didn't invest due to the opportunities he gets now from the market.

Kahle (2000) used a distinctive method for determining the value of the long-term IPOs return. Concluded that the market where there is a net seller get good return from IPOs. The returns on IPOs are affected by the pre or post traded period.

The association within the long run earning on IPOs and the insider trading is very much positive. The returns on the IPOs are not negative in both methods. When the firm confident about the timing of the IPOs then they must need to present the IPOs to the public because this is the time of getting the maximum benefits from sharing of IPOs

Lowry, Officer, \& Schwert (2010) tell that the return on the IPOs is very significant. And returns on 
IPOs changes from time to time. And the return should be high when the market trend is upward. As we already know that the efficient market has a higher information asymmetry.

The return on the IPOs is significantly high over the time. The spreading among the result of the returns is related. The returns on the IPOs for the investor are positive and have a good correlation for past issued IPOs. But this is also having instability as a camper to the securities traded in the secondary market. The underwriter is responsible for the success and failure of the IPOs in the market. The other important thing is that how the firm set his price. It has a great effect on the investor about their interest in investing.

One of the best ways to sell the IPOs is the auction method by which we can easily sell our good number of shares without any barrier of the reputed underwriter or timely presentation or some flop in the prize. In this the underprizing of the shear is also very much limited.

Khurshed, Mudambi\& Goergen (1999) state that there are some important factors which are affecting the IPOs performance such as the firm previous performance, administrative action, the plan or project of the firms. The firm which is already in operation is performing very well than the firm which is newly founded and wants to issue IPOs

The firm which took the services of the good underwriter will able to get a good result from the market. We can forecast IPOs performance on the company previous performance.

\subsection{Underwriter in Shariah-compliant}

Abu Bakar \& Uzaki (2014) argued about the "Initial Public Offering (IPO) Underpricing, Underwriter Reputation and Oversubscription: Evidence from Shariah Compliant Companies listed on the Malaysian Stock Exchange (MSE)" they mentioned the IPOs underpricing and the relation of an underwriter. The underpricing of IPOs is very good in Malaysia that they have even good numbers than their neighbouring countries. The relationship between the underwriter and underpricing is that less reputed underwriter has a less underpricing of the shares while the underwriter who has good reputation has a great underpricing. Another important thing is that the multiple 
regression shows that the reputation of the underwriter and the over-contribution was irrelevant result on the performance of underpricing of IPOs.

In the Shariah-compliant IPOs, the role of the underwriter is also evaluated as positive. If the firm hired a reputed underwriter, then the IPOs can do better. The relation of the IPOs performance and the underwriter in Shariah-compliant is positive.

\subsection{Underwriter reputation and IPOs performance in Pakistan stock exchange (KSE)}

Khan (2016) asked that there is a lot of the literature on the presentation of IPOs. The financial market is associated with the underpricing of the IPOs sharing in the market. The scale of the underpricing of the IPOs varies in different geographical location due to its economic and political factor which is affecting the market. These factors are affecting the market too much and there is so much distraction in the under developing countries market. The country-specific location and its internal affair are very much related to the efficacy of the market which is directly linked to the performance of the shares and IPOs issued in the market.

Sohail and Nasr (2007) estimate that IPOs are directly affected by the existing vagueness, size which firm is offering, the firm its size capital structure and the nature of the firm, firm value, profits of the firm and previous performance of the firm related to the firm value.

The trends of pricing of IPOs in Pakistani market are somehow related to the developed country markets and there is so less variation in the share of IPOs and performance of IPOs is good in the market. There is more chance to get a more profit from a share for the investor who buys IPOs of a firm and bears a risk instead of that who are interested in the day trading concepts.

The long-run performance of IPOs is very good in the market. The return on the first day on which the IPOs are offered for sale is positive. And it is varying from 0.19 to 63.75 present.

Yar and Javid (2014) describe the relationship of initial returns on IPOs related to the firm structure and its performance related to its repo. The underpricing of the share is a way to get an opportunity of sealing a maximum share in the market. One of the main functions of the firm which they are going to achieve when they offer their share to the 
public is to distribute the possession of the firm from a few hands to others. This also helps the firm to transfers of the risk. The main purpose beside other which we are already discussed is to spread the proprietorship of the firm from a few too many and to achieve the liquidity of the market.

The relationship between the ownership structure and IPOs underpricing of the firm is directly proportion to each other. The factor which affects the IPOs performance is risk and the mandate of the investor which are interested in the IPOs.

Sadaqat, Akhtar, \& Ali (2011) concluded that the IPOs listed on the Karachi stock exchange has also good returns as like to other countries. To get a good return from the IPOs performance instead of the day to day buying and selling one should get a maximum profit by purchasing of equity from primary market holding the shares and then sell them after some time. The returns on IPOs is at an average when the market trend is in economically adjusted, the return is quite high when there is a successful economy and IPOs performance get weakening in the time of downturn stage.

There are more than 52 present returns in the economy in some sectors i-e "Oil \& Gas Exploration \& Oil \& Gas Marketing, Commercial Banks, Power Generation \& Distribution, Chemical and Miscellaneous". In every year the average return from the performance of IPOs the investor gets is positive. The performance of Pakistani IPOs at dissimilar stages has positive returns.

\subsection{International market data}

Gompers \& Lerner (2003) argued that the performance of the IPOs in the "NASDAQ" market. The performance of the IPOs in the market is quite good and the return on the IPOs is above average and there is more return on the IPOs which investor buy the securities and hold them for some time.

The IPOs performance in the market is quite good and the return for the investor is above average. The return of IPOs is underperformance and when an investor is interested and buy the security and hold it for some time then he can get a return from the security.

Guo, Lev, \& Shi (2006) state that the IPOs performance initial return and the IPOs long-run performance are affected by the information that is an irregularity in the market and also by the misappraisals of the investor. The underwriter affects the IPOs 
performance in the long run as well as in the short run. Although the firm is doing good and the profit of the firm is quite high but there are some of the factors which affects the firm IPOs.

Mezhoud \& Boubaker (2011) concluded that it is very important for the IPOs at the initial stage as underpricing. The various factors are in between which being affect the IPOs under and overpricing. The return of the both under and overpricing varies by the time and the investor liking towards the share. One of the other important factors that are affecting the IPOs performance is the market trend if the market trend is in upward direction then the return from the security that is offered to the public first time give us positive return while on the other hand when it's downward then there is some variation in the returns that are initially listed.

In the Paris stock exchange, the association among the firm Size and market capitalization, and the IPOs underperformance are positive. The information that revolves around the market has also a great impact on the firm IPOs. There is a strong correlation among the underpricing and the performance of the IPOs. The underpricing of the IPOs will attract the more investor and the demand of the IPOs increased. The underpricing of the IPOs and the firm size is directly proportioned to each other. If the firm has a huge size, then his IPOs can perform well in the primary market and when the size is small or medium then it will grab a less investor toward its self.

Geest \&Frederikslust (2001) says that the private firm equity has more return then the equity of the non-private firms. The IPOs underpricing in the private firm is very much less than the non-private firms. There is no any important alteration between these two.

The issuing of IPOs with a fixed price offering has chances of underpricing then the firm choose a relax offer of pricing. In free mode, the investor can easily adjust it with the way that he wants to invest in the IPOs. There is very less underpricing found in the firms which are very old in the market. The earlier listed firm has strong shareholder based so the firm can able to get more investors. If the shareholder has a negative observation about the IPOs, then the IPOs will be under praised at the start.

Vong \& Trigueiros (2010) tried to determine the short-term performance of the equity. Able to set that the IPOs are generally affected by the performance of the 
underwriter and its reputation. The IPOs underperformance is linked with the performance and reputation of the underwriter in different stretch and circumstances.

In the performance of the IPOs, the leading role is played by the underwriter. The IPOs performance and the reputation of the underwriter are very much related to each other.

Thorsell \& Isaksson (2014) estimate that when the firm is going for issuing the IPOs for the first time it is to change the firm from the private sector to the public sector. Some of the factors that are affecting the performance of the IPOs in the Swedish market is the board of directors of the firm. Directors' knowledge, ability, skills, involvement, understanding in linking presidencies and regular tenancy. These are some of the factors which will cause the IPOs underrepresentation in the market. However, in the long-run performance of the market isn't affected by the board of directors or director.

In the Swedish market, the IPOs performance is affected by the interconnecting presidencies in previous studies but now it is evaluated that there is no important association among the long-term performance of IPOs and the executive skills. The IPOs performance is related to the information present in the market and the information reflects on the price of the share. In the efficient market, the price of the IPOs is changed with the new information without taking any time. In the open market, the prices which are pre-offer are not set. And in the offering of the price the offer may be set as when the IPOs are going for the presentation in the market.

Anderson, Chi, \& Wang (2000) state that the market return in the Chi Next in China on IPOs is about 33.5 per cent and for the investor who buys and hold IPOs the return is about -45.7 per cent however it varies from the small and medium type of firms. The return of stock where an investor buys and then for some time takes with him and then the sale is lower.

The careful market search is very essential for the investor when he is going to invest in the market. The underperformance and underpricing of the IPOs are covered by the issuing of new policies in the market which will help the IPOs to do well in the market. 
Bansal \& Khanna (2012) argued that some of the factors which influence the Indian IPOs as underpriced are company's oldness, the pricing structure process of IPOs, Relation of proprietorship assembly, size of securities which firm are issuing as IPOs.

Zamanian, Khodaparati, \& Mirbagherijam (2013) say that the IPOs extended track presentation are very much related to the dealing capacity of the firm, the firm size, $\mathrm{P} / \mathrm{E}$ Ratio. While the short-run returns of the IPOs are related to the dealing capacity and firm magnitude. Although the proprietorship of the business has not any important influence on the IPOs return of the firm in any long or a short term.

The return in the Tehran market is negative because of the overpricing of the IPOs in the short as well as in the long-run performance. The IPOs short run are affected by the size at which the company is going to offer to the public. Some of the changes which are required in the rulemaking is to enhance the regulatory authority, estimating of IPOs price, IPOs effectiveness and smooth out time.

\section{Conclusions}

Based on the above evidence, it is concluded that the relation of a good underwriter with the performance of the IPOs is very much inter-related. If the underwriter has a good reputation in the market, then he can gather more investors. The lead underwriter has a good relationship with the investor so it will also help him. If the firms are not interested in the hiring of a well-reputed underwriter, then the IPOs of the firm will not perform well regarding that firm who is hiring a good reputed underwriter while other things remain the same.

The performance of the IPOs, in the long run, are also related to the underwriter reputation. Most of the studies indicate that the underwriter reputation is very much related to the IPOs long-run performance in the market.

The investor and the relation of reputed underwriter is very helpful in the success of the IPOs. The investor pays more attention to those IPOs who are offered by the reputed underwriter.

One of the other prospects is that we can highlight that to take the services of the more underwriter than one is very much batter in the performance of the IPOs. If we have an underwriter's team which may include several underwriters, then they can manage the 
IPOs very well as compared to a single underwriter. The investor trusts also increase on that rather than one underwriter.

The return on the IPOs is related to the performance of the underwriter. There are numerous capital markets in the world which have underpricing difficulties and most of the time the performance of the IPOs is underpriced so most of the investor should attract to it. The firm who offered their shares to primary market as an IPOs get an extreme capital when they have a hire a reputed underwriter there is very optimistic association among the IPOs performance in the primary market and the reputation of the underwriter. The underpricing of the share when IPOs is presented on the very first day is due to recognized to the will to attract the investor to buy a maximum share. The information related to the share price is however controlled by the underwriter which will help the investor to invest.

The long-run earning of the IPOs is related to the underwriter reputation. Due to the worldwide investing opportunities, the investor becomes more aware of investing in the market. Because to diversifying the risk pattern an investor tries to invest in a portfolio which has a low correlation with others. If the firm value being not at that position so investor didn't invest due to the opportunities he gets now from the market. So, besides the underwriter reputation, the firm also needs to maintain the firm value in term of profit While we see the performance of the Shariah-compliant it will be concluded that the reputed underwriter has also a positive relation in the issuing of IPOs

The performance of the IPOs in Pakistan is very much related to the developed countries market. One can get a maximum profit from the IPOs. There is much more profit for an investor who buys a security and then stay with it for some time instead of day sale. In the Pakistani market, the relationship between the ownership structure and IPOs underpricing of the firm is directly proportional to each other.

\section{References}

Abu Bakar, N., \& Uzaki, K. (2014). Initial Public Offering (IPO) Underpricing, Underwriter Reputation and Oversubscription: Evidence from Shariah -Compliant 
Companies listed on the Malaysian Stock Exchange (MSE). The IAFOR Journal of Business and Management, 1(1), 814-826.

Akkus, O., \& Cookson, J. A. (2014). Endogenous Matching, Underwriter Reputation, and the Underpricing of Initial Public Offerings, 1-40.

Anderson, H., Chi, J., \& Wang, Q. (2000). Initial Public Offerings (IPOs) on ChiNext: Good Investment or Not? 1-45.

Bajo, E., Chemmanyr, T. J., Simonyan, K., \& Tehranian, H. (2014). Underwriter Networks in Initial Public Offerings, 1-55.

Bansal, R., \& Khanna, A. (2012). Determinants of IPOs Initial Return: Extreme Analysis of Indian Market. Journal of Financial Risk Management, 1(4), 68-74. http://doi.org/10.4236/jfrm.2012.14012

Ghosh, C., Petrova, M., Feng, Z., \& Pattanapanchai, M. (2012). Does IPO Pricing Reflect Public Information? New Insights from Equity Carve-Outs. Financial Management, 41(1), 1-33. http://doi.org/10.1111/j.1755-053X.2012.01176.X

Gompers, P. A., \& Lerner, J. (2003). The Really Long-Run Performance of Initial Public Offerings: The Pre-Nasdaq Evidence. Journal of Finance,58(4), 1355-1392. http://doi.org/10.1111/1540-6261.00570

Guo, R. J., Lev, B., \& Shi, C. (2006). Explaining the short- and long-term IPO anomalies in the US by R\&D. Journal of Business Finance and Accounting, 33(3-4), 550-579. http://doi.org/10.1111/j.1468-5957.2006.00610.x

Huang, W. (2011). Underwriter Reputation, IPO Initial Underpricing and Underwriting spread: Evidence from Chinese Stocks Market.

Jay R. Ritter. (1991). The Long-Run Performance of IPOs. Journal of Finance.

Kahle, K. M. (2000). Insider trading and the long-run performance of new security issues, 1-49.

Karolyi, A., Lehn, K., \& Mulherin, H. (1999). Factors Affecting Investment Bank Initial Public Offering Market Share * Craig G. Dunbar University of Western Ontario Factors Affecting Investment Bank Initial Public Offering Market Share.

Khan, S. (2016). Short-Run Underpricing of Initial Public Offerings (IPOs): A Conceptual Review.pdf. International Business Management. 
Khurshed, A., Mudambi, R., \& Goergen, M. (1999). On the Long-Run Performance of IPOs 1. Reading, (July), 1-42. http://doi.org/10.1108/03074350710748759

Kovner, A. (2010). Federal Reserve Bank of New York Staff Reports Do Underwriters Matter? The Impact of the Near Loss of an Equity Underwriter, (July).

Lee, C. (2011). Underwriter reputation and the decision to go public. Journal of Finance and Accountancy, 1-21. Retrieved from https://www.aabri.com/manuscripts/10710.pdf Loo, J., Lee, D., \& Yi, J. (1999). Profitability and Volatility of IPO Firms and Underwriter Reputation, 4(2).

Lowry, M., Officer, M. S., \& Schwert, G. W. (2010). The Variability of IPO Initial Returns. Journal of Finance,65(2), 425-465. http://doi.org/10.1111/j.15406261.2009.01540.x

Method, M., \& Boubaker, A. (2011). Determinants of the Components of IPO Initial Returns: Paris Stock Exchange. International Journal of Accounting and Financial Reporting, 1(1), 190-211. http://doi.org/10.5296/ijafr.v1i1.986

Neupane, S., \& Thapa, C. (2013). Underwriter reputation and the underwriter-investor relationship in IPO markets. Journal of International Financial Markets, Institutions and Money, 24(1), 105-126. http://doi.org/10.1016/j.intfin.2012.11.005

Razafindrambinina, D., \& Kwan, T. (2013). The Influence of Underwriter and Auditor Reputations on IPO, 5(2), 199-213.

Sadaqat, S., Akhtar, M. F., \& Ali, K. (2011). An Analysis of the Performance of IPO - A Study on the Karachi Stock Exchange of Pakistan. International Journal of Business and Social Science, 2(6), 275-285.

Sohail, M. K., \& Nasr, M. (2007). Performance of initial public offerings in Pakistan. International Review of Business Research Papers, 3(2), 420-441.

Song, K., Choi, Y. S., \& Lee, J. E. (2012). Revisiting the certifying role of financial intermediaries on IPOS. Journal of Applied Business Research, 28(5), 1017-1034.

Song, W.-L. (2003). Financial infrastructure, underwriter reputations, and securities fraud. Available at SSRN 417220. http://doi.org/10.2139/ssrn.417220

Thorsell, A., \& Isaksson, A. (2014). Director experience and the performance of IPOs: Evidence from Sweden. Australasian Accounting, Business and Finance Journal, 8(1), 
3-24. Retrieved from http://www.scopus.com/inward/record.url?eid=2-s2.084924990118\&partnerID=tZOtx3y1

van der Geest, R. a., \& van Frederikslust, R. a. I. (2001). Initial Returns and Long-Run Performance of Private Equity-Backed Initial Public Offerings on the Amsterdam Stock Exchange. SSRN Electronic Journal, 1-31. http://doi.org/10.2139/ssrn.269810

Vithanage, K., Chung, R., \& Neupane, S. (2016). Multiple Lead Underwriter IPOs and Heterogeneous Beliefs, 1-50.

Vong, A. P. I., \& Trigueiros, D. (2010). The short-run price performance of initial public offerings in Hong Kong: New evidence. Global Finance Journal, 21(3), 253-261. http://doi.org/10.1016/j.gfj.2010.09.003

Wang, J. (2003). Does Underwriter Reputation Affect the Performance of IPO Issues ?, 8(3), 17-41.

Yar, M. M. S., \& Javid, A. Y. (2014). Liquidity benefits from underpricing: Evidence from initial public offerings listed at Karachi Stock Exchange. PIDE Working Papers, 1(101), 1-44.

Zamanian, G., Khodaparati, S., \& Mirbagherijam, M. (2013). Long-Run and Short-Run Returns of Initial Public Offerings (IPO) of Public and Private Companies in Tehran Stock Exchange (TSE) Market. International Journal of Academic Research in Business and Social Sciences, 3(2), 2222-6990. 